\title{
Beyond Goods and Services: Toward a Nietzschean Critique of Capitalism
}

Michael Kilivris

\begin{abstract}
In this article, I examine an underexplored area of Nietzsche's thought, namely his comments regarding several integral aspects of capitalism. In particular, I argue against the interpretation of Nietzsche as a bourgeois ideologue, by showing how his claims about money-making, money itself, work, workers, pleasure, and the marketplace amount to a critical view of capitalism's essential features. In addition, I distinguish his critical standpoint from more familiar critiques of capitalism such as that of Marx, using Nietzsche's own criticisms of socialism to propose that, in contrast, Nietzsche's perspective vis-à-vis capitalism is what I call aristocratic. By "aristocratic" I refer to the attitude or "pathos of distance" Nietzsche possesses in relation to such things as money-making, work, and the marketplace, rather than some literal aristocracy that he supposedly defends. Finally, I offer a brief discussion of how Nietzsche's aristocratic perspective can assist the Marxist critique today by rejecting one of capitalism's strongest ideological supports, that is, the myth of capitalists as great individuals.
\end{abstract}

Key words: Nietzsche, Marx, capitalism, aristocratic perspective

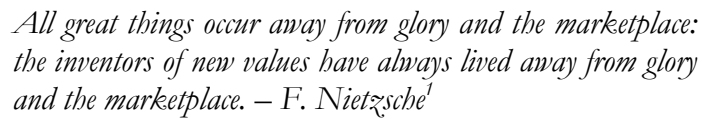

$\mathrm{I}$

$\mathrm{n}$ this article, I examine an underexplored area of Nietzsche's thought, namely his comments regarding several integral aspects of capitalism. In particular, I argue against the interpretation of Nietzsche as a bourgeois ideologue, ${ }^{2}$ by showing how his claims about money-making, money itself, work, workers, pleasure, and the marketplace amount to a critical view of capitalism's essential features. This view differs, however, from more familiar critiques of capitalism such as that of Marx. Thus I also distinguish the socialist critique of capitalism from what I call Nietzsche's aristocratic critique, using Nietzsche's own criticisms of socialism as my guide. By Nietzsche's

${ }^{1}$ Friedrich Nietzsche, Thus Spoke Zarathustra, trans. by R. J. Hollingdale (London: Penguin Books, 1969), 79.

${ }^{2}$ I attribute this reading of Nietzsche primarily to Ayn Rand and Francis Fukuyama. I directly characterize, and challenge, their appropriation of Nietzsche in the final section.

(c) 2011 Michael Kilivris

http://www.kritike.org/journal/issue 10/kilivris december2011.pdf ISSN 1908-7330 
"aristocratic" perspective I refer to the attitude or "pathos of distance" Nietzsche possesses in relation to such things as money-making, work, and the marketplace, which he regards not as immoral, but as beneath the values and aims of "free spirits." In making my case, I first briefly discuss Nietzsche's criticisms of socialism as a moral, nihilist, and populist movement originating from below, or ressentiment. This section will also serve to show how the socialist, and by implication the Marxist, critique of capitalism differs in kind from Nietzsche's criticisms of capitalism. In the next section, I deal exclusively with Nietzsche's attacks on various foundational elements of capitalism, drawing from his early to his last writings. Together these attacks reveal not only that Nietzsche was no apologist for the bourgeoisie, but also that he saw himself and other free spirits as above them. Finally, in a short section I discuss the implications of Nietzsche's aristocratic critique for our own time. Therein, I propose that the Nietzschean perspective constructed herein can supplement the Marxist critique today insofar as it challenges the notion of capitalists as great individuals, an ideological belief crucial to the persistence of capitalism.

\section{From Below: Nietzsche's Critique of Socialism}

Nietzsche appears to have two closely related problems with socialism. The first has to do with the view of exploitation as unjust and historical. For Nietzsche, such a position depends on a conventionally moral perspective, which he also considers nihilistic, in the sense of being life-denying or "antinature." The second problem deals with the populist dimension of socialism. In Nietzsche's view, not only does this make socialism a movement of the "herd"; it also explains its moral standpoint which, as in the case of Christian morality, he considers a kind of "slave morality" arising from ressentiment. In this section, I will briefly discuss these problems that socialism presents for Nietzsche, the main implication being that unlike Nietzsche's own criticisms of capitalism, the socialist, and by extension the Marxist, critique of capitalism is one originating from below. ${ }^{3}$

The socialist critique of capitalism centers on class exploitation, which Marx, for example, explains as the extraction of "surplus value" from the laboring class by the owning class. ${ }^{4}$ The socialist not only views exploitation in moral terms as unjust, alienating, etc., but also as a historical phenomenon that can and will one day vanish. For instance, Marx and Engels espouse this position in the Communist Manifesto when they refer to the proletarian revolution

${ }^{3}$ My primary agenda in this section is thus to provide a sense of Nietzsche's views of socialism in general, rather than of Marxism in particular, as Nietzsche gives no signs of having engaged with Marx's thought. Nor do I wish to reconstruct the Marxist critique of capitalism, as a step toward differentiating it from that of Nietzsche. Instead, I intend to use Nietzsche's own criticism of socialism to reveal the basic character of the socialist, and by extension the Marxist, critique of capitalism.

${ }^{4}$ Cf. Karl Marx, Capital, Volume I: A Critique of Political Economy, Chapter 9: "The Rate of Surplus Value," trans. by Ben Fowkes (London: Penguin, 1990). 
as "inevitable." 5 For Nietzsche, both of these perspectives on exploitation the moral and the historical - depend on conventional presuppositions that he considers within good and evil, rather than "beyond" good and evil. In the case of the moral critique of exploitation, Nietzsche argues that it assumes a normative sense of "right" and "wrong," which is then projected onto a phenomenon that in itself is amoral. As he writes in On the Genealogy of Morals, "To talk of right and wrong as such is senseless; in themselves, injury, violation, exploitation, destruction can of course be nothing 'wrong,' in so far as life operates essentially - that is, in terms of its basic functions-through injury, violation, exploitation, and destruction, and cannot be conceived in any other way." "As for the socialist view of exploitation as historical, Nietzsche contends that it rests on a similarly traditional notion of moral perfectibility, even as it claims to be "scientific":

... everywhere people are now raving, even under scientific disguises, about coming conditions of society in which "the exploitative aspect" will be removed-which sounds to me as if they promised to invent a way of life that would dispense with all organic functions. "Exploitation" does not belong to a corrupt or imperfect and primitive society: it belongs to the essence of what lives, as a basic organic function; it is a consequence of the will to power, which is after all the will of life. ${ }^{7}$

That socialism's moral and historical critique of exploitation ignores the "essence" of life - the will to power - renders it nihilistic as well, according to Nietzsche. An equivocal term in Nietzsche's thought, nihilism here means life-denying, world-slandering, or anti-nature more so than the sense of meaninglessness following the death of God. Hence Nietzsche can find Platonism and Christianity nihilistic, since both negate life or nature qua will to power, affirming its antithesis in the ideas of Being and God, respectively. Nietzsche sees a secular version of this tendency in socialism, insofar as it likewise refuses life or nature qua will to power by morally denouncing exploitation, and imagining that it can and will be overcome at the "end of

${ }^{5}$ Karl Marx and Friedrich Engels, The Communist Manifesto, trans. by Samuel Moore (London: Penguin Classics, 2002), 233. The question of whether Marx was a moralist or a scientist or both is a source of much debate. Cf. Steven Lukes, Marxism and Morality (Oxford: Oxford University Press, 1987).

${ }^{6}$ Friedrich Nietzsche, On the Genealogy of Morals, trans. by Douglas Smith (Oxford: Oxford University Press, 1996), 56-57. Marx too takes the position that there no objective morality, for instance in The German Ideology, when he asserts that "the ideas of the ruling ideas," including morals, are in every epoch the ruling ideas." Karl Marx, The German Ideology, in Karl Marx: Selected Writings, ed. by David McLellan (Oxford: Oxford University Press, 1977). However, Marx also relies on a moral framework, secular humanist perhaps, to level his critique of capitalist injustice.

${ }^{7}$ Friedrich Nietzsche, Beyond Good and Evil, in Basic Writings of Nietzsche, ed. and trans. by Walter Kaufmann (New York: Modern Library, 1992), 393. 
history." Socialism's aim of establishing mutual restraint from exploitation, claims Nietzsche, is "a will to the denial of life, a principle of disintegration and decay." Against this denial, Nietzsche again advocates acceptance of exploitation as the essence of life or nature: "Here we must beware of superficiality and get to the bottom of the matter, resisting all sentimental weakness: life itself is essentially appropriation, injury, overpowering of what is alien and weaker; suppression, hardness, imposition of one's own forms, incorporation and at least, at its mildest, exploitation." 9

In opposing exploitation, socialism claims solidarity with the exploited, giving it a populist dimension that Nietzsche, the staunch solitary and elitist, views as an alliance with the herd. While Nietzsche's concept of the herd does not specifically apply to the working class, an important qualification to be revisited below, he sometimes uses it when describing the would-be beneficiaries of a socialist society. Thus, as in his analysis of ascetic priests, who promote "herd organization" to ease the suffering of the "depressed," "listless," "weak," "sick and sickly," Nietzsche argues that socialists promise the "universal, green-pasture happiness of the herd" for those seeking security, comfort, and ease. In distinguishing his own conception of "free spirits" from the so-called free spirits of "democratic taste and "modern ideas," Nietzsche writes of the latter:

... only they are unfree and ridiculously superficial, above all in their basic inclination to find in the forms of the old society as it has existed so far just about the cause of all human misery and failure-which is a way of standing truth happily upon her head! What they would like to strive for with all their powers is the universal, greenpasture happiness of the herd, with security, lack of danger, comfort, and an easier life for everyone; the two songs and doctrines which they repeat most often are "equality of rights" and "sympathy for all that suffers"and suffering itself they take for something that must be abolished. ${ }^{10}$

Socialism's normative morality, denial of life or nature, and solidarity with the herd, make its critique of capitalism look, from the Nietzschean perspective, like one arising from below, which is to say from ressentiment. Indeed, Nietzsche often describes socialism in terms similar to those he uses when discussing Christian morality, which he proposes is a slave morality originating "out of the spirit of ressentiment." In one of his final aphorisms on

${ }^{8}$ Ibid.

${ }^{9}$ Ibid

${ }^{10} \mathrm{Ibid}$., 244. This passage plays on two additional similarities Nietzsche sees between socialism and Christianity: 1) their messianism, which socialism secularizes in positing a kind of heaven on earth; and 2) their aversion to suffering, which socialism is ultimately intended to abolish. 
socialism, from The Will to Power, he characterizes socialists as "the envious," with "poisonous and desperate faces," recalling his reference to the Christian's "poisonous eye of ressentiment" in On the Genealogy of Morality. Additionally, Nietzsche asserts that socialism as a whole is a "hopeless and sour affair... an attack of sickness," much like the "slave revolt in morality" he attributes to the first Christians. For Nietzsche, then, socialism is marred by a perspective through which capitalism and capitalists can only be seen as above. As such, socialism lacks the pathos of distance from which there is never a "higher," only a "below." In the following section, I will show how Nietzsche's own criticisms of capitalism are characterized by just this pathos of distance, thus making his perspective, in contrast to the socialist's, aristocratic rather than moral, nihilist, and populist.

\section{From Above: Nietzsche's Aristocratic Critique of Capitalism}

Nietzsche's critique of socialism is sometimes interpreted ipso facto as an affirmation of capitalism. Hence thinkers such as Rand and Fukuyama have looked to Nietzsche for support of their pro-capitalist positions. However, while Nietzsche undeniably endorsed a class system or division of labor, he was highly critical of the remaining aspects of capitalist society, many of which are foundational. In this section, I reveal this dimension of Nietzsche's thought by piecing together a number of his comments on money-making, money itself, work, workers, pleasure, and the marketplace. In the aggregate, these claims prove, contra Rand and Fukuyama, that Nietzsche was just as critical of capitalism as he was of socialism. Yet, unlike socialism's critique from below, Nietzsche criticizes capitalism from an aristocratic perspective or pathos of distance. Thus I also demonstrate how Nietzsche sees himself and other free spirits as above such things as money-making, work, and the marketplace.

In the case of one of the most fundamental feature of capitalism, money-making, Nietzsche was hostile from his earliest to his last writings. In Untimely Meditations, his second major publication, he writes, "Nowadays the crudest and most evil forces, the egoism of the money-makers and the military despots, hold sway over almost everything on earth."11 Elsewhere he talks of the "hugely contemptible money economy" as well as the "harmful" effects of the "economic principle of laissez faire." These comments come from the third meditation, "Schopenhauer as Educator," in which Nietzsche posits the goal of society to be not the creation of wealth, but the "production of individual great men" in the specific realm of Bildung or culture (i.e., philosophers, artists, and saints). Since "that and nothing else" is humanity's task, Nietzsche regards money-making as a force or obstacle to be overcome. Discussing the stranglehold of money-making on the pursuit of culture in his own time, Nietzsche writes the following, sounding more timely than untimely:

11 Friedrich Nietzsche, Untimely Meditations, trans. by R. J. Hollingdale (Cambridge: Cambridge University Press, 1997), 150. 
Here there is a hatred of any kind of education that makes one solitary, that proposes goals that transcend money and money-making... Precisely the opposite of this is, of course, held in esteem by the morality that here counts as valid: namely, a speedy education so that one may quickly become a money-earning being, yet at the same time an education sufficiently thorough to enable one to earn a very great deal of money. A man is allowed only as much culture as it is in the interest of general money-making and world commerce he should possess... ${ }^{12}$

If this seems like a young, naïve Nietzsche, the later Nietzsche of Ecce Homo, his penultimate work, expresses a similar view. In reflecting therein on his Untimely Mediations, Nietzsche asserts that they "prove that [he] was no Jack the Dreamer." The third and fourth essays (the latter is on Wagner), he claims, exalt the "hardest self-love, self-discipline" as the pathway to "a higher concept of culture," and are thus "full of sovereign contempt" for the idols of the day such as financial "success." Nietzsche then suggests that in describing Schopenhauer and Wagner, he was really expressing himself. ${ }^{13}$ Indeed, earlier in Ecce Homo Nietzsche writes of his own self-love and self-discipline, which was likewise remote from money-making: "But that is how I always lived. I had no wishes. A man over forty-two who can say that he never strove for honors, for women, for money!"14 To the extent that he strove for anything - in this same passage, Nietzsche shares that he "became what he was" without "struggle," "striving," or "willing" - it was the greatness of his heroes, most of whom were cultural figures (Montaigne, Spinoza, Goethe), and none of whom were money-makers.

Nietzsche rejects money-making not just because it stands in the way of achievement in the realm of culture, but also because he sees money itself as yet another way humans attempt (vainly) to establish security. Today, those who value money see themselves, and are seen by many, as "realists." The cliché "money talks" illustrates this view, suggesting that everything besides ensuring economic survival is just airy-fairy idealism. However, for Nietzsche, money is no less an object of idealism than the idea of God, which he sees as offering the ultimate comfort of "metaphysical solace." Like the idea of God, money is believed to promise psychological comfort, albeit through material or economic security. Money thus becomes a kind of fortress thought to keep at bay need, want, pain, and unhappiness. Yet for Nietzsche such a fortress is undesirable, not to mention unattainable, since he sees life as "becoming,"

12 Ibid., 165.

13 "Schopenhauer and Wagner or, in one word, Nietzsche": Friedrich Nietzsche, Ecce Homo, in Basic Writings of Nietəsche, ed. and trans. Walter Kaufmann (New York: Modern Library, 1992). 737.

${ }^{14}$ Ibid., 737. 
which "does not aim at a final state."15 Hence, free spirits are "full of malice against the lures of dependence that lie hidden in honors, or money, or offices, or enthusiasms of the senses."16 Preferring to "live dangerously," free spirits live with becoming rather than (nihilistically) against it.

In chasing the illusion of security, most money-makers must spend the vast majority of their lives working. "[A] society in which the members continually work hard," Nietzsche writes, "will have more security: and security is now adored as the supreme goddess." 17 To many, especially in the United States where the Protestant work ethic still reigns supreme (even as it increasingly intermingles with hedonism), work itself has become a goddess. It is considered an expression of strength and will-power. Moreover, it is associated with individualist notions such as self-development. According to Nietzsche, however, work has more in common with ascetic self-denial. In $O n$ the Genealogy of Morals, he puts work on par with herd organization when it comes to providing relief from self-loathing. Hence the blessing in the "blessing of work," Nietzsche argues, is that "the interest of the suffering man is completely distracted from his suffering-that nothing enters his consciousness but activity, continual and repeated activity, and thus leaves little room for suffering."18 He goes on to call this a "forgetting of self" and "incuria su?" (self-neglect). In The Dawn, he goes further by arguing that work "obstructs" self-development:

Behind the glorification of "work" and the tireless talk of the "blessings of work" I find the same thought as behind the praise of impersonal activity for the public benefit: the fear of everything individual. At bottom, one now feels when confronted with work-and what is invariably meant is relentless industry from early till late- that such work is the best policy, that it keeps everybody in harness and powerfully obstructs the development of reason, of covetousness, of the desire for independence. For it uses up a tremendous amount of energy and takes it away from reflection, brooding, dreaming, worry, love, and hatred; it always sets a small goal before one's eyes and permits easy and regular satisfactions. ${ }^{19}$

Nietzsche's disdain for work even led him to offer a solution to the problem facing "workers in factory slavery." This comes as a surprise, since Nietzsche seems to have generally held that such workers are necessary for the

15 Friedrich Nietzsche, The Will to Power, trans. by Walter Kaufmann and R. J. Hollingdale (New York: Vintage Books, 1968), 378.

16 Nietzsche, Beyond Good and Evil, 245.

17 Friedrich Nietzsche, The Dawn, in The Portable Nietssche, ed. and trans. by Walter Kaufmann (New York: Viking Press, 1968), 82.

18 Nietzsche, On the Genealogy of Morals, 112.

${ }^{19}$ Nietzsche, The Dawn, 82. 
sake of (high) culture. In the early essay "The Greek State," he argues that "In order to have a broad, deep and fertile soil for artistic development, the overwhelming majority must be slavishly subjected to the necessities of life in order to serve a minority beyond the measure of its individual needs." 20 However, in a passage from The Dawn called "The impossible class," Nietzsche presents an alternative to the "indecent serfdom" of capitalism as well as socialism. As a third way - to "protest against the machine, against capital" and the "socialistic pied pipers" - Nietzsche recommends an "era of a vast swarming out from the European beehive" in declaration that "as a class," workers are a "human impossibility." 21 In "savage fresh regions," they could cease caring about "the rapid rise and fall of power, money, and opinions," and begin to focus on "inner worth," "mastery of myself," "beautiful naturalness," and "heroism." 22 Here, Nietzsche posits an idea of liberation completely beyond the paradigm of labor, in which he sees socialism as still caught up. Thus, in addition to fleeing capitalist exploitation, workers would also escape the socialist belief that reforming the system, even revolution, would fundamentally change their servitude:

Phew! to believe that higher pay could abolish the essence of their misery-I mean their impersonal serfdom! Phew! to be talked into thinking that an increase in this impersonality, within the machinelike workings of a new society, could transform the shame of slavery into a virtue! Phew! to have a price for which one remains a person no longer but becomes a gear! ${ }^{23}$

Nietzsche discourages work because for him play is the more valuable activity. Counter to the self-denial of work, play allows for self-cultivation outside the confines of utility and productivity. ${ }^{24}$ Thus, play for Nietzsche is associated with Dionysian creativity rather than hedonism..$^{25}$ Yet, despite this as well as his many denunciations of Epicureanism, Nietzsche continues to be misinterpreted as an advocate for hedonism, even the kind prevalent in capitalist societies today, where pleasure is tightly entangled with conspicuous

${ }^{20}$ Quoted in Rudiger Safranski, Nietzsche: A Philosophical Biography, trans. by Shelley Frisch (New York: W. W. Norton and Company, 2002), 74

${ }^{21}$ Friedrich Nietzsche, The Dawn, 82.

22 Ibid., 90. Nietzsche even urges these ex-workers to turn to philosophy and other areas of culture, which have "become a laughingstock to [them]." Ibid., 90.

23 Ibid., 89-90.

${ }^{24}$ Here I agree with Nancy Love who, in comparing Marx and Nietzsche, argues that the former prioritizes (free) labor, while the latter subordinates labor to play: "For Nietzsche, labor for needs, even labor as a need, denies life as will to power. Life is the purposeless play of the child. Unlike purposive production to overcome obstacles, play is not a means to an end, but an end in itself. Play expresses life's value in the moment." Nancy Love, Marx, Nietzsche, and Modernity (New York: Columbia University Press, 1986), 192.

25 Play also contributes to Bildung in the sense of self-overcoming, for Nietzsche, since he holds that it is only in play, particularly Bildung qua culture, that the opposing internal forces of the Dionysian and Apollonian converge. 
consumption. Ishay Landa reflects and challenges this view when discussing how, in the context of popular culture, James Bond can be seen as a Nietzschean hero due in part to his "refined hedonism," for example his preference for (shaken) martinis. ${ }^{26}$ While Landa makes a case for this interpretation, he rightly points out that Bond's hedonism is "thoroughly disciplined" and "with a purpose," as opposed to the "aimless, un-heroic, cowardly hedonism of the rich who are characterized precisely by shunning anything resembling 'dangerous work'."27

However, in both theory and practice Nietzsche takes a harder line against hedonism, and by extension consumerism, than Landa admits. Theoretically, Nietzsche considers hedonism a close relative of Christianity, insofar as both seek to minimize pain and suffering. In Beyond Good and Evil, Nietzsche talks of a "tranquillizing (for example, Epicurean or Christian) medicine... the happiness of resting, of not being disturbed, of satiety, of finally attained unity, of a 'sabbath of sabbaths'." 28 As such, hedonism violates Nietzsche's "formula for greatness," amor fati, which demands the affirmation of pleasure and pain, joy and suffering. Practically, while Nietzsche paid close attention to his gustatory habits, he did so in the name of strength, not pleasure. Hence, his guiding concern was, "how do you, among all people, have to eat to attain your maximum of strength, of virtu in the Renaissance style, of moralinefree virtue." 29 We also learn in this discussion that Nietzsche "abstained" from alcohol: "Alcohol is bad for me: a single glass of wine or beer in one day is quite sufficient to turn my life into a vale of misery... [I] cannot advise all more spiritual natures earnestly enough to abstain entirely from alcohol: $W$ ater is sufficient." 30 There is perhaps no better proof than this that Nietzsche did not conceive of the Dionysian in hedonistic terms. ${ }^{31}$

Neither Nietzsche's thought nor his life can be used to justify hedonism or consumerism because they altogether transcend the realm of goods and services, that is, the marketplace. Contra Fukuyama and (especially) Rand, who see "big" entrepreneurs as realizations of Nietzsche's free spirits and even Übermenschen, Nietzsche in fact looked down upon such people. In a section of Thus Spoke Zarathustra called "Of the Flies of the Market-place," Nietzsche describes them as "small men," "actors," "buffoons," and "heroes of the hour," who receive glory only because "The people have little idea of

26 Ishay Landa, The Overman in the Marketplace: Nietzschean Heroism in the Marketplace (Lanham: Lexington Books, 2007), 8.

27 Ibid., 174-175.

28 Nietzsche, Beyond Good and Evil, 302.

${ }^{29}$ Nietzsche, Ecce Homo, 693.

30 Ibid., 694-695.

31 A rival example would be Nietzsche's discussion, in On the Genealogy of Morals, of asceticism as the true nature of philosophers, Nietzsche himself included. Deleuze captures this point nicely in his book on Spinoza: "Nietzsche understood, having lived it himself, what constitutes the mystery of a philosopher's life. The philosopher appropriates ascetic virtueshumility, poverty, chastity — and makes them serve ends completely his own, extraordinary ends that are not very ascetic at all, in fact." Gilles Deleuze, Spinoza: Practical Pbilosophy, trans. by Robert Hurley (San Francisco: City Lights Books, 1988), 3. 
greatness." 32 By contrast, the true "great men," though they rule "imperceptibly," are the real centers around which the world revolves, not because they excel at inventing things, but because they are inventors of new values. Of course, as opposed to Rand's claim that the "businessman's tool is values," for Nietzsche the creation of new values takes place beyond the marketplace. ${ }^{33}$ Hence he asserts, "All great things occur away from glory and the marketplace: the inventors of new values have always lived away from glory and the marketplace." 34

The foregoing paragraphs reveal that Nietzsche dismisses much that is essential to capitalism. Thus it cannot be maintained, as Rand and Fukuyama hold, that Nietzsche embraced capitalism and/or regarded capitalists as realizations of his Übermensch. For it has also been shown that Nietzsche saw himself and other free spirits as above such things as money-making, work, and the marketplace. Thus I call Nietzsche's perspective vis-à-vis capitalism aristocratic. By this I mean the pathos of distance that he possesses in relation to the most important of capitalism's defining features. In On the Genealogy of Morals, Nietzsche defines the pathos of distance as "the enduring, dominating, and fundamental overall feeling of a higher ruling kind in relation to a lower kind, to a "below'."35 It is this "feeling of a higher kind," moreover, that distinguishes Nietzsche's critique from that of socialists. As discussed above, the latter oppose capitalism on primarily moral and populist grounds. By contrast, Nietzsche criticizes various aspects of capitalism for being beneath him and other free spirits. To put it another way, whereas socialists take issue with capitalism's immorality, Nietzsche condemns its tendency to foster mediocrity. In the following section, I will further address the latter claim, as well as discuss its implications for our own time.

\section{Twilight of the (New) Idols?}

It is well-nigh impossible for people today, especially in the United States, to see how anyone (much less a philosopher) could be above a capitalist. This is largely because in such societies, which are otherwise democratic, orders

32 Interestingly, Rand references this section in The Fountainhead, when Ellsworth Toohey states, "It is not our function - paraphrasing a philosopher whom we do not like - to be a fly-swatter.” Ayn Rand, The Fountainhead (New York: Bobbs-Merrill, 1943), 360.

33 Ayn Rand, Capitalism: The Unknown Ideal (New York: Signet, 1967), 45.

34 Nietzsche, Thus Spoke Zarathustra, 79. In a more explicit statement about entrepreneurs, along with manufacturers, Nietzsche refers to them as "uninteresting persons," excluding them from a "higher race": "The manufacturers and entrepreneurs of business probably have been too deficient so far in all those forms and signs of a higher race that alone make a person interesting." Friedrich Nietzsche, Gay Science, trans. by Walter Kaufmann (New York: Vintage Books, 1974), 107.

35 Nietzsche, On the Genealogy of Morals, 13. The terms "higher" and "lower" here refer to psychological types (i.e., "strong," "weak"), rather than social or economic classes. Thus, one need not be a member of an actual aristocracy to have an aristocratic perspective. I make a similar point when discussing Nietzsche's concept of the herd in the final section. 
of rank track mainly along economic lines. ${ }^{36}$ Hence the term "elite" almost invariably refers to a certain segment of the business community, while everyone else is relegated to "average" or "ordinary." Calling the owning class the elite, furthermore, is not just a statement of fact, which by itself is irrefutable. It is also a designation of excellence or greatness, as when financiers are described as "the best and the brightest," for example. It is this latter sense of the word that is both revealing and problematic from a Nietszchean standpoint. For it shows that money-makers have won, or been given, the second victory of greatness; the first victory being their ownership of much of the planet. If Marxism is the protest against capitalism's first victory, then Nietzsche's aristocratic perspective can be said to contest the second, thus making it a strategic supplement to the Marxist critique, which remains essential as ever. ${ }^{37}$ In this section, I offer a short further discussion of the need for Nietzsche's aristocratic critique. This leads to a more direct confrontation with Rand's and Fukuyama's appropriation of Nietzsche, which I reject via Nietzsche's concepts of "last man" and the herd.

Nietzsche's aristocratic critique is needful today because capitalism's hold on individuals is not just economic, but also psychological. In addition to being owners, the economic elite are now idols wielding a gravitational pull on the values of the broader society. These values revolve principally around money, status, and pleasure, together constituting what Horkheimer and Adorno once called the "religion of success," which has since only intensified and spread. While the collective worship of economic success stems in large part from necessity, since in free-market economies one is either "successful" or struggling, it is also the affirmation of an ideal, insofar as success is associated with things beyond self-preservation such as achievement and greatness. Hence in the United States, "success stories" like C.E.O.'s, entrepreneurs, and until recently bankers and financiers, are not simply those who have "made it"; even more so, they are seen as heroic individuals, inspiring awe and emulation.

This awe ensures the persistence of capitalism as much as private property. For, in Sartrean terms, awe is a choice which, when continually made by a vast number of people, has the cumulative effect of maintaining the dominance of the awed. So why is the decision to exalt capitalists made? It seems that apart from the noted necessity of prioritizing success, this choice stems from a deeper value judgment of the capitalist as great or heroic. Of course, such a valuation can be explained in terms of ideology or false consciousness. However, as of yet ideology-critique has been ineffective in challenging it. I believe that this is partially due to Marxism's tendency of

36 This is not to ignore the glaring difference between formal and actual democracy, or the hierarchies based on race, ethnicity, sex, and sexual orientation. It is simply to highlight that, at least in theory, so-called liberal societies are politically democratic, but economically stratified.

37 Thus I concur with Sartre, who saw Marxism as "the unsurpassable philosophy of our time." Jean-Paul Sartre, Search for a Method, trans. by Hazel Barnes (New York: Knopf, 1963). Yet I agree as well that existentialists - Nietzsche and Sartre himself - can be interpreted in such a way as to help the Marxist cause. 
retaining the aura of capitalists by continuing to think of them as the "elite," if a villainous rather than heroic one. By contrast, no such tendency can be found in Nietzsche's aristocratic perspective, which refuses to grant elite status to capitalists whatsoever. To the contrary, as will be elaborated below, Nietzsche devalued such individuals to the ranks of the herd or last men. Thus a Nietzschean critique would appear to be of significant help to Marxists, insofar as it attacks a crucial value judgment (that capitalists are great individuals) upon which capitalism in part thrives.

Yet, two of the most prominent voices lauding capitalists as great individuals belong to Rand and Fukuyama, both of whom cite Nietzsche as a kindred spirit in this regard. Rand claimed that Nietzsche "beat [her] to all her ideas," one of which is that selfishness is a virtue, making the industrialist the exemplar of excellence. ${ }^{38}$ Similarly, Fukuyama proposes that capitalists embody the Nietzschean ideal of greatness by striving for more recognition than bestowed by democracy, which sees all as equal. At the very least, he argues, "The classical capitalist entrepreneur described by Joseph Schumpeter is therefore not Nietzsche's last man."39 However, Rand's and Fukuyama's positions reveal more about their own thinking, shaped by the conditions of twentieth-century American society, than that of Nietzsche. While Rand's "ethical egoism" certainly overlaps in ways with Nietzsche's "master morality," her interpretation of egoism and individualism in strictly economic terms differs markedly from Nietzsche's more psychologically and aesthetically inflected individualism; hence Rand's great individual is the businessperson, while Nietzsche's is the philosopher and/or artist. ${ }^{40}$ For his part, Fukuyama is unwilling to look beyond the domain of capitalism for contemporary alternatives to the last man, though he is able to entertain doubts about the connection between Nietzsche and (would-be) capitalists. Hence he also states, in apparent contradiction of the claim above,

Those earnest young people trooping off to law and business school, who anxiously fill out their resumes in hopes of maintaining the lifestyles to which they believe themselves entitled, seem to be much more in danger of becoming Nietzsche's last men... It is hard to detect great, unfulfilled longings or irrational passions lurking

38 Anne C. Heller, Ayn Rand the World She Made (New York: Anchor Books, 2009), 42. Apparently, Rand adopted the phrase of her older cousin, who suggested she read Nietzsche "because he beat you to all your ideas." Barbara Branden, The Passion of Ayn Rand (New York: Random House, 1986), 45. 316.

${ }^{39}$ Francis Fukuyama, The End of History and the Last Man (New York: Free Press, 2006),

40 As her career progressed, Rand became increasingly critical of Nietzsche, particularly his call to go beyond good and evil. While this is an apt criticism, it is interesting to note that she did not turn away from Nietzsche because she saw his thinking as incompatible with capitalism. 
just beneath the surface of the average first-year law associate. ${ }^{41}$

Fukuyama thus refutes his own, and Rand's, appropriation of Nietzsche, getting right to the heart of their mistake. For the capitalist has more in common with Nietzsche's last man - the "most contemptible" man than his free spirit, much less the Übermensch. The concept of the last man is part and parcel of Nietzsche's critique of modern, mediocre man. However, it is not just, as Fukuyama generally holds, directed towards democratic (or socialist) man; it can also be viewed as an indictment of the bourgeois or capitalist. While it may seem that if anything, Nietzsche implicates the middle class in his discussion of the last man - "Nobody grows rich or poor any more: both are too much of a burden" 42 - it is unclear whether he is referring here to literal wealth and poverty. Generally, he is much more wont to associate these terms with psychological states as when, for example, he asserts, "Our 'rich' are poorest of all." 43 In any case, there are several additional descriptions of the last man that could be construed as targeting money-makers, even the notion of homo economicus as such. For example, a reference to work: "They still work, for work is entertainment. But they take care the entertainment does not exhaust them." 44 As well, the refrain of the last man, "We have discovered happiness" suggests the industrialists of Nietzsche's time who promised an earthly paradise of material comfort. From a contemporary point of view, this phrase brings to mind both the advertising executive and the satisfied customer, each of whom claims to have found happiness through consumption.

If the capitalist can be included in Nietzsche's theory of the last man, then they can also be considered a part of the herd, implying that the so-called elite are in fact, from a Nietzschean perspective, the "average," "ordinary," or "mediocre." Above, I claimed that Nietzsche's concept of the herd has no necessary connection to any social or economic class. Rather, it more accurately refers to a shared psychological trait, similar to Kierkegaard's "crowd," typified by dependency on others, particularly where values are concerned. Hence Nietzsche describes the herd-animal in psychological terms as "weak," that is, unable to posit and live by their own values. Although the economic elite appear to have created the dominant values today - money, status, and pleasure - historically these have been associated with the "masses," "many," "mob," or "multitude." In ancient Greece, Plato and Aristotle characterized the herd as those who love money, honor, and pleasure, as opposed to wisdom. Likewise, in the early modern period, Spinoza saw "Riches, Fame, and the Pleasures of Sense" as "the objects pursued by the multitude." 45 As shown

${ }^{41}$ Fukuyama, The End of History, 336.

42 Nietzsche, Thus Spoke Zarathustra, 46.

${ }^{43}$ Nietzsche, Will to Power, 41.

${ }^{44}$ Nietzsche, Thus Spoke Zarathustra, 46.

45 Benedict de Spinoza, On the Improvement of the Understanding, The Ethics, Correspondence, trans. by R. H. M. Elwes (New York: Dover Publishing, 1955), 3-5. 
above, Nietzsche shares this position, even as he critiques the opposing values of asceticism. From this perspective, then, the only difference between the elite and the average comes down to having the objects of these values; the former has more of them, and the latter less. But to want the same, according to Nietzsche, is to be the same: "No herdsman and one herd. Everyone wants the same thing, everyone is the same: whoever thinks otherwise goes voluntarily into the madhouse." 46 The truly different and great individual, for Nietzsche, would thus appear to live beyond goods and services.

\section{Concluding Remarks}

In the above, I have tried to accomplish three objectives: 1) to demonstrate that Nietzsche cannot be called upon to ideologically underwrite capitalism, despite Rand's and Fukuyama's claims to the contrary; 2) to reveal that Nietzsche was in fact critical of key aspects of capitalism, and further, in a different manner (aristocratic) than socialism; and 3) to suggest how Nietzsche's aristocratic perspective can aid the Marxist critique today by refusing to give capitalists the second victory of greatness, which is one of their strongest ideological supports. Hopefully, I have also shown the merit of examining this underexplored dimension of Nietzsche's thought, which I believe has more radical potential for our time than the others. While his critique of religion and his "campaign against morality" are certainly still "untimely" in parts of the world, elsewhere (particularly the United States and Europe) they have lost much of their dangerousness. In particular, the critique of Christianity and its morality is nearing obsolescence in these societies, whose ways of life have become fundamentally secular. Hence the "madman" is no longer the one proclaiming that God is dead, but rather that God is still alive. But secularization has allowed for a new religion to rise up, one based on the ideas and values of capitalism. If Nietzsche's thinking can also yield a critique of this new religion, then he will continue to be - like Marx - as radical as ever.

Department of Philosophy, Hunter College, United States of America

\section{References}

Branden, Barbara, The Passion of Ayn Rand (New York: Random House, 1986).

Deleuze, Gilles, Spinoza: Practical Philosophy, trans. by Robert Hurley (San Francisco: City Lights Books, 1988).

Fukuyama, Francis, The End of History and the Last Man (New York: Free Press, 2006).

Heller, Anne C., Ayn Rand the World She Made (New York: Anchor Books, 2009).

Landa, Ishay, The Overman in the Marketplace: Nietzschean Heroism in the Marketplace (Lanham: Lexington Books, 2007).

${ }^{46}$ Nietzsche, Thus Spoke Zarathustra, 46. 
Love, Nancy, Marx, Nietzsche, and Modernity (New York: Columbia University Press, 1986).

Marx, Karl, Capital, Volume I: A Critique of Political Economy, trans. by Ben Fowkes (London: Penguin, 1990). , and Friedrich Engels, The Communist Manifesto, trans. by Samuel Moore (London: Penguin Classics, 2002). , The German Ideology, in Karl Marx: Selected Writings, ed. by David McLellan (Oxford: Oxford University Press, 1977).

Nietzsche, Friedrich, Beyond Good and Evil, in Basic Writings of Nietzsche, ed. and trans. by Walter Kaufmann (New York: Modern Library, 1992). The Dawn, in The Portable Nietzsche, ed. and trans. by Walter Kaufmann (New York: Viking Press, 1968). , Ecce Homo, in Basic Writings of Nietzsche, ed. and trans. by Walter Kaufmann (New York: Modern Library, 1992). On the Genealogy of Morals, trans. by Douglas Smith (Oxford: Oxford University Press, 1996). Thus Spoke Zarathustra, trans. by R. J. Hollingdale (London: Penguin Books, 1969). , Untimely Meditations, trans. by R. J. Hollingdale (Cambridge: Cambridge University Press, 1997). , The Will to Power, trans. by Walter Kaufmann and R. J. Hollingdale (New York: Vintage Books, 1968).

Rand, Ayn, Capitalism: The Unknown Ideal (New York: Signet, 1967).

Rand, Ayn, The Fountainhead (New York: Bobbs-Merrill, 1943).

Sartre, Jean-Paul, Search for a Method, trans. by Hazel Barnes (New York: Knopf, 1963).

Spinoza, Benedict de, On the Improvement of the Understanding, The Ethics, Correspondence, trans. R. H. M. Elwes (New York: Dover Publishing, 1955). 